\title{
THE CONCEPT OF WASATIYYAH IN CONSUMPTION: AN ANALYSIS FROM ISLAMIC FINANCIAL JURISPRUDENCE
}

\author{
Hossain Biplob* \\ Md. Faruk Abdullah**
}

\begin{abstract}
In Islam, consumption is not just the act of fulfilling human wants, but also an action that contributes to the well-being of ourselves and others. The goal of consumption in an Islamic framework is to satisfy personal needs that bring the pleasure of Allah and contribute to social development. Therefore, this study has been designed to discuss the concept of consumption in Islam by reviewing several journal articles in the field of Islamic jurisprudence. The study explores the act of consumption based on the moral and religious principles of Islamic shariah. In Islam, Muslims are guided to consume based on permissibility, wholesomeness, cleanliness, priority, and maqasid al-shari'ah (higher objectives of Islamic law). Most significantly, the study focuses on the principle of moderation (wasatiyyah) as it relates to consumption, as wastefulness and miserliness have an impact not only on individuals but also society and the economy. The study expects to improve Muslim consumer behaviour by acting as a reminder of the moral principles underlying consumption.
\end{abstract}

Keywords: Wasatiyyah, Consumption, Islamic Jurisprudence, Moderation, Muslim.

\section{Introduction}

Islam is a religion that offers a justified and ethical worldview. It believes that worldly life is not just designed to fulfil the desires of the duniyah (this world) but also of the akhirah (Hereafter). Although Islam emphasises the akhirah, it does not refute duniyah. It allows people to fulfill their earthly desires while not losing spiritual orientation. Indeed, Islam balances the necessity of physical and spiritual life. ${ }^{1}$ In Islam, every individual action, whether an act of worship or of daily affairs, should follow the concept of moderation as Islam disallows stinginess and extravagance. According to Islam, stinginess deprives people of their haqq (rights). On the other hand, extravagance leads to an unbalanced life. $^{2}$ 
Recently, a craze for luxurious consumption has increased all over the world. Modern consumers are spending a lot to satisfy their desires. This trend is also evident in many Muslim countries, including Saudi Arabia, Lebanon, Kuwait, Malaysia, and Pakistan. Many Muslims nowadays prefer to live a luxurious life that is assumed by others to reflect their social status. Unfortunately, it triggers financial difficulty among them. ${ }^{3}$

For example, excessive spending on luxurious items is a major factor affecting Malaysian household debt. According to the Census and Economic Information Centre (CEIC), Malaysian household debt has reached an alarming level in recent years. The proportion of Malaysian household debt to GDP was 86.1 per cent in $2013,86.78$ per cent in 2014 , and 82.7 per cent in 2019 . The government and its related agencies are working hard to improve such consumer behaviour. However, their performance does not seem to be effective. As a result, various kinds of financial problems (poor liquidity, low saving, credit defaults, bankruptcy) are increasing. ${ }^{4}$

Current Malaysian consumer behaviour demands an approach to the problem be found. This study of consumer behaviour from an Islamic perspective is therefore significant, as Islam guides humans to consume based on a hierarchy of needs. It prohibits extravagance or miserliness so that others never experience a shortage in necessities. Moreover, religious identity has been identified as having a realistic effect on Muslim consumer behaviour in Malaysia. ${ }^{5}$ Therefore, it is believed that the current study will benefit local Muslim consumers as it may serve as a guide when they are making consumer decisions. It could also work as a reference point for both academics and practitioners.

This paper first discusses the concept of moderation and consumption in Islam. It then analyses Islamic principles regarding consumption, including the theory of permissibility and the principles of wholesomeness, cleanliness, priority, and moderation. Finally, it investigates the benefits of becoming a moderate consumer and provides a conclusion with some policy recommendations.

\section{The Concept of Moderation in Islam}

In the past, the concept of moderation was discussed only by scholars of Qur'an and hadith. Nowadays, it has gained the attention of many commentators from different fields. Al-Wasatiyyah is an Arabic term derived from the root wasat, which roughly means 'just, moderate, excellent, and professional. ${ }^{6}$ More precisely, wasatiyyah means something that is good and positioned between two extremes, which it balances without ignoring any rulings of maqasid al-shari'ah (higher objectives of Islamic law). ${ }^{7}$ 
Prior to the Prophet Muhammad, the Jews focused only on earthy desire, avoiding spirituality. Christians and al-Sabi'in, on the other hand, prioritised faith and ignored worldly affairs. When the Qur'an was revealed, these two extremes were harmonised. ${ }^{8}$ The Qur'an says: "Thus, We have made of you an ummah justly balanced, that you might be witnesses over the nations, and the Messenger a witness over yourselves." 9

The term wasatiyyah is mainly adopted from the phrase ummatan wasatan (an ummah justly balanced) mentioned in the above verse. In this verse, Allah calls Muslims a moderate people. There are various interpretations by shariah scholars regarding the word wasatan in this verse, as illustrated in the below chart.

\begin{tabular}{|l|l|}
\hline \multicolumn{1}{|c|}{ Scholars } & \multicolumn{1}{c|}{ Interpretations } \\
\hline Imam al-Qurtubi & $\begin{array}{l}\text { Wasat } \text { is fair and best. It does not mean taking a } \\
\text { middle position between good and bad. }{ }^{10}\end{array}$ \\
\hline Imam al-Tabari & $\begin{array}{l}\text { Wasat } \text { means the chosen, the good, the fair, which is } \\
\text { different from extreme attitudes. }{ }^{11}\end{array}$ \\
\hline al-Razi & $\begin{array}{l}\text { Wasat } \text { means the most humble and perfect, the best } \\
\text { and most fair. }{ }^{12}\end{array}$ \\
\hline
\end{tabular}

Another Islamic scholar, al-Sallabi, defined moderation as a value that enables us to make the most appropriate or balanced moral and behavioural judgement. If there are two positive things, moderation is following the relatively better one; if there are two negative things, moderation is taking the lesser evil; if there are two choices, one bad and one good, moderation means adopting the good one. ${ }^{13}$ Similarly, Rashid Rida defined wasat as justice and the best option. The 'best option' is the middle ground between two choices. ${ }^{14}$

Hamka further clarified the concept of wasatiyyah. He stated that people are divided into three groups based on their desires. The first group includes those who only follow their desires, having no control over them. As a result, they often sacrifice their wealth and reputation to fulfill their desires. The second group neglects all their desires and involve themselves in self-denying practices. However, the third group stands between these two by not following all their desires blindly, but fulfilling only those which are lawful, without any wastage or stinginess. ${ }^{15}$

Wasatiyyah is therefore taking the middle path, whether the latter is related to behaviour, attitude, motion, or discourse. Moderation means taking a median position between two opposites: excessiveness and miserliness, truth and falsity. 


\section{Consumption in Islam}

In conventional economics, consumption is defined as the act of completing the utility of a product that satisfies one's needs and wants. The ultimate goal of consumption is self-satisfaction. Therefore, it is considered the ultimate phase of the economic process in a capitalist economy. ${ }^{16}$ There is a doctrine in philosophy that human wants are unlimited but resources are limited; if an individual's single desire is satisfied, another will arise, and if that is satisfied, another will arise, etc. In this way, a person struggles throughout their life to satisfy an endless chain of desires. Therefore, some economists criticise the conventional perspective of consumption as it has no contribution to human well-being. The act of consumption is viewed as a self-interested act with materialistic values, where a moral agenda is absent. Therefore, there are no restrictions in conventional economics for achieving self-satisfaction. ${ }^{17}$

In Islam, however, consumption has a greater interpretation: it is considered a noble act which not only satisfies human wants but also ensures spiritual and social well-being. In other words, the act of consumption has multiple dimensions in Islamic economics. Firstly, it is an act of self-satisfaction through fulfillment of need. Secondly, it is a spiritual act guided by God-consciousness (taqwa). In this spiritual dimension, consumption must adhere to the principles of shariah, displaying feelings of patience and thankfulness that promote selfdignity. Thirdly, consumption is a social act directed by ethical values and social preferences. For instance, consumption must be free from selfishness and wastefulness so that other people in society do not feel a shortage of resources, products, and services. ${ }^{18}$

Thus, in Islam the act of consumption has multiple dimensions. It is the individual action of attaining self-benefit through the fulfillment of need. But it is also a social action whereby the fulfillment of need is achieved by avoiding social cost and while displaying a willingness to cooperate and share social benefits. Moreover, consumption is also a spiritual action whereby an individual has God consciousness and adheres to the principles of Qur'an and Sunnah, with a feeling of thankfulness and contentment that aims at achieving His pleasure.

\section{Expenditure upon Consumption}

Expenditure here means wealth and income spent upon consumption. According to Ibn Sina, there are three forms of expenditure in Islam: (1) expenditure upon personal consumption, (2) expenditure upon social consumption, and (3) expenditure upon future consumption. ${ }^{19}$ 
Concerning the first category, an individual must spend for himself and his dependents, including wife, children, and parents, without stinginess or extravagance. ${ }^{20}$ Allah mentions in the Qur'an: "But the father of the child shall bear the costs of the mother's food and clothing on a reasonable basis." ${ }^{21}$ The Prophet Muhammad also mentioned in a hadith: "A dinar which is spent for the sake of Allah, a dinar which is spent on freeing a slave, a dinar which you give in charity to a person and a dinar which you spend on your family; the greatest of these in reward is that which you spend on your family." ${ }^{22}$ Therefore, spending to satisfy personal and family needs is an act of virtue in Islam.

The second category of expenditure is for the sake of Allah. This type of expenditure is only carried out if an individual has excess resources after fulfilling his personal and family needs. This form of expenditure has two divisions: obligatory (zakat) and voluntary (sadaqah). ${ }^{23}$ Social consumption is found in the Qur'an, where Allah says: "And establish the prayer and pay the zakat and bow with those who bow." ${ }^{24}$ The encouragement of social consumption is also found in the Sunnah, where the Prophet Muhammad says: "There is not a day in which two angels descend, and one of them says: 'Oh Allah compensate the one who spends freely.' And another angel says: 'Oh Allah let annihilation come upon the one who is niggardly." ${ }^{25}$

The third category of expenditure, saving for future consumption, involves planning and saving to meet future requirements. However, spending on future needs is only permissible if an individual has an excess of income after spending on the first two categories just mentioned. ${ }^{26}$ The Qur'an has warned about wealth accumulation before covering personal needs and social consumption: "Who is stingy and enjoins upon people stinginess and conceals what Allah has given them from His bounty - and we have prepared for the disbelievers a humiliating punishment."

\section{Principles of Consumption in Islam}

The principles of consumption in Islam are based on the instructions of the Qur'an and Sunnah. Those guiding principles work as a basis for making consumer behaviour meaningful and purposive. They run as follows.

\section{Principle of Permissibility}

In Islam, the act of consumption is not just a way of completing the utility of a product. It is also a way of creating an ontological connection between the Creator and His creation. ${ }^{27}$ Almighty Allah commands human beings to enjoy what He has provided between the sky and the earth: "Eat of that which We have 
bestowed upon you as food lawful and good, and keep your duty to Allah in whom you believe." ${ }^{28}$ Thus, consuming lawful items is a way of connecting with Allah. The principle of permissibility indicates that an individual can consume anything (consumable) freely, unless there is clear evidence of a prohibition in the Qur'an and Sunnah. Allah has set the boundary of consumption for the benefit of human beings. What is permissible and good preserves human well-being and what is prohibited causes physical, mental, and spiritual harm. Therefore, a true believer must focus on the form of his consumption. Muslims should pay attention to anything consumed; for instance, a Muslim is prohibited from eating pork and dead meat. ${ }^{29}$ As Allah says: "He hath only forbidden you dead meat, and blood, and the flesh of swine, and that on which any other name hath been invoked besides that of God. But if one is forced by necessity, without willful disobedience, nor transgressing due limits, then is he guiltless for God is forgiving most merciful."

Additionally, Muslim consumers should avoid doubtful items for which rulings are unclear, especially as there are now various products and services in the market that are subject to intense volatility and gharar (uncertainty). Prophet Muhammad suggested people avoid doubtful things. It was narrated by Numan bin Bashir: "I heard the messenger of Allah saying, 'Both legal and illegal things are evident but in between them there are doubtful things and most of the people have now knowledge about them. So whoever saves himself from these suspicious things saves his religion and his honor. And whoever indulges in these suspicious things is like a shepherd who grazes near the hima (private property) of someone else and at any moment he is liable to get in it." ${ }^{30}$ This hadith indicates that the ruling of halal and haram is very clear in Islam. However, there are some items that are doubtful. Muslims should avoid these doubtful things; when a Muslim avoids doubtful matters and occupies himself only with what is permissible and wholesome, he feels mentally strong. By contrast, if he engages in dubious acts, his heart becomes weak and more likely to fall into $\sin .{ }^{31}$

\section{Principles of Wholesomeness and Cleanliness}

In Islam, an individual is ordered to follow the principles of wholesomeness and cleanliness when consuming goods. Wholesomeness means something healthy and nutritious, while cleanliness implies something pure, fresh, and free of impurity. ${ }^{32}$ Allah says in the Qur'an: "O mankind eat of that which is lawful and wholesome in the earth. And follow not to the footstep of the devil. Indeed, he is an open enemy for you." In this verse, Allah commands mankind to consume lawful and pure things only. He also mentions, "Eat of the good things which We have provided you." 33 The word tayyib is used in the Qur'an to mean anything 
pure, wholesome, and conducive to health; something is not halal unless it is also tayyib, or suitable for the human body because it is free from dirt and impurity. Moreover, the suitability of a product depends on the physical condition of its consumer. For instance, people with diabetes are instructed by doctors not to have sweet things, even though sweet things are halal. ${ }^{34}$

\section{Principle of Priority}

Islam also suggests that individuals consume based on the principle of priority. As consumption must be done in a way that attains benefit and prevents harm, a consumer should follow the principle of priority as set by shariah. ${ }^{35}$ The Qur'an and Sunnah discuss several types of consumption, which should be prioritised thus:

\section{Personal Consumption}

The highest priority, where an individual must put personal and family consumption first. Allah says: "They ask you, what should they spend; 'whatever you spend of the good is to be for parents and relatives and orphans and the needy and travelers. And whatever you do of good - indeed, Allah knows of it." 36 It further mentions, "and they ask you, what they should spend. Say, the excess. Thus, Allah makes clear to you the verse that you might give thought. ${ }^{\prime 37}$ In this last verse, Allah uses the word al-afwa, which indicates extra after satisfying one's self and family. ${ }^{38}$

\section{Social Consumption}

The spending of wealth and income in the form of charity and social philanthropic activities to satisfy social needs, such as healthcare, education, and infrastructure. This type of activity is only carried out if an individual has excess resources after satisfying personal and family consumption. ${ }^{39}$ The evidence for social consumption is found in the Qur'an, where Allah says: "whosoever believes in the unseen, establishes prayer and spends out of what we have provided for them." 40

\section{Consumption under Maqasid al-Shari'ah}

Consumption based on the hierarchy of needs given in the maqasid alshari'ah runs as follows:

i. Daruriyyat: This first category of human need includes what is essential. These are also called human necessities and include food, shelter, clothes, and so on. ${ }^{41}$ The Prophet Muhammad discussed these basic 
needs, saying: "This is enough for you in this world: if it meets your hunger, [and] covers your body." ${ }^{2}$ Humans are highly encouraged to work hard to satisfy their basic needs. If someone is unable to work due to disability, Islam places responsibility on the Muslim community to provide for them. ${ }^{43}$

ii. Hajiyyat: This second category of human need includes those things which make human life easy and comfortable. Although not essential, the absence of hajiyyat consumption may lead to difficulty and inconvenience. For instance, a house is a basic need, but a good quality house with lots of space is comfort. ${ }^{44}$

iii. Tahsiniyyat: This third level of human need further improves quality of life by adding elegance. Such consumption must be without excessiveness or extravagance. Tahsiniyyat consumption may involve ornamentation, recreational activities, and hobbies. ${ }^{45}$

\section{Principle of Moderation}

As discussed, the Qur'an names the Muslims Ummatan Wasatan, the moderate people. It instructs a balance between extreme points in every step of life. In regards to consumption, Muslims must follow moderation in eating, drinking, clothing, and spending. Spending less than expected (miserliness) or more than expected (wastefulness) are both prohibited in Islam. ${ }^{46}$ Before clarifying the concept of moderation, it is crucial to understand the ideas of miserliness, excessiveness, and wastefulness.

\section{Miserliness}

Miserliness is a situation where an individual does not spend on himself and his family according to his means. The one who does this is called a miser. Miserliness in consumption is when people do not consume enough to satisfy their necessities and comforts, even though they have the means to do so. ${ }^{47}$ Miserliness has been prohibited in Islam as it is a self-denying practice. Allah says: "who hoards up their wealth that Allah has bestowed upon them of His bounty. For disbelievers, we prefer a shameful doom." ${ }^{48}$ According to al-Shawkani, there are three forms of miserliness in Islam:

i. Miserable Consumption: the abstinence of an individual from consuming things required by both himself and his family. Such consumption brings misery. 
ii. Selfish Consumption: narrow consumption focused only on selfsatisfaction. In such a situation, an individual refuses to share with others.

iii. Ungrateful Consumption: a form of consumption lacking spiritual consciousness, when an individual consumes things without being grateful to Allah. ${ }^{49}$

\section{Excessiveness (Israf)}

A form of consumption exceeding what is sufficient is called excessive. In this regard, Allah says: "O children of Adam, wear your beautiful apparel at every masjid, and eat and drink but be not excessive. Indeed, Allah does not like the excess." In this verse, Allah uses the word israf, which means excessive or beyond limit. Israf is consumption beyond what is needed - that is, willful overconsumption. It happens when consumption surpasses moderation. ${ }^{50}$ The word israf is also found in the hadith: "The Prophet saw Saad in ablution. He then said: what is this excess? Saad then replied: is there excess in ablution? He said; Yes, indeed, even if you are on the bank of a flowing river." ${ }^{51}$ In this hadith, the Prophet warned against excessive water usage while taking ablution, which could lead to water shortages elsewhere in society. ${ }^{52}$

\section{Wastefulness (Tabdhir)}

Another type of consumption found in the Qur'an is wastefulness, or the wasting of an item or product either wholly or in part. This type of consumption is strictly prohibited in Islam. ${ }^{53}$ Allah says: "do not spend wastefully." ${ }^{54}$ Here the word tabdhir embodies three meanings: unlawful consumption, or consuming what is prohibited (wine, pork, etc.); unnecessary consumption, or consuming things that are either unneeded or are merely for fulfilling desire; and inappropriate consumption, such as a student spending his limited income on going to the cinema instead of on buying books and stationery. This form of consumption is not only meaningless, it is also sinful because wealth and income are spent unjustly. ${ }^{55}$ Instead of these three forms of consumption, Islam recommends moderation and balance. The use of wealth and income to satisfy personal needs should be done in a way that does not create scarcity for others. ${ }^{56}$ Allah says: "Eat and drink but be not prodigals. Indeed, He does not love the prodigals," and "Those who spend [wisely] are neither prodigal nor grudging; and there is a fire station between the two." ${ }^{57}$ In regard to this, Prophet Muhammad said: "Allah will bestow His grace upon a person who works decently, spends wisely and can spare the excess to anticipate the days (when) he becomes poor." ${ }^{58}$ Therefore, Muslims are required to be moderate in consumption and consumptive expenditure. Over-consumption in the form of excess and wastage is not preferred as it creates an imbalance in 
resources. Similarly, under-consumption by avoiding desire is not favoured in Islam as it leads to miserable consumption and a miserable life.

\section{Benefits of Becoming Moderate in Consumption}

In our personal life, being moderate in consumption can prevent and manage chronic disease as a balanced diet helps ensure healthy development. It is important that each food group is consumed in sufficient quantity, without being excessive or niggardly. ${ }^{59}$ Excessive eating and drinking causes obesity and creates various types of diseases (high blood pressure, diabetes, etc.), while undereating causes low blood pressure and gastric problems. Therefore, balance is required for health and fitness. ${ }^{60}$

Wasatiyyah in consumption is also significant for personal financial management. This is because an individual may earn a lot but, if there is no control over consumption, he or she might still fall into debt. Moderation encourages people to spend according to their means so that they will not fall into debt. ${ }^{61}$ Moreover, when an individual becomes moderate in consumption, it increases the possibility of saving. There is a huge need for savings in personal life as it shields against future financial shock and helps support long-term healthcare and better education. ${ }^{62}$

Wasteful and excessive consumption can lead to the unequal distribution of resources in society, depriving many people of their rights. On the other hand, moderation in consumption reduces wastage and ensures proper distribution of resources. ${ }^{63}$ Balanced consumption helps people build their wealth, reducing unplanned and excessive spending. Moreover, it enables them to become zakat payers and thereby contribute to social development. Excessive consumption by the rich, by contrast, increases excessive demand for goods and services, ultimately causing inflation and reducing the purchasing power of the poor. Likewise, miserliness minimises demand for goods and services, lessening production and causing unemployment. ${ }^{64}$ As economic growth is directly proportional to household consumption, the former will decrease as consumption decreases. Consumer household spending must therefore be balanced to ensure stability in the economy. ${ }^{65}$

\section{Conclusion and Policy Recommendations}

In Islam, consumption is considered a potential act of virtue that contributes to human well-being. In this context, Islam suggests that individuals follow a framework of desires based on daruriyyat (necessities), hajiyyat (comforts) and 
tahsiniyyat (embellishments). However, human beings are created in such a way that they love wealth and prefer to have more. Hence, there is always a possibility they may seek consumption in the wrong way, by transgressing the boundaries of permissibility and ignoring social need. Therefore, Islam sets up these three principles to ensure nobody in society lacks basic needs.

To promote the concept of moderation in consumption, this study recommends the following:

- The improvement of Islamic financial education. The vast majority of Muslims are not aware of the concept of moderation in consumption. As a result, excessiveness and wastefulness are common. The government and educational authorities should take the required initiatives to improve Islamic financial education among the people. The concept of moderation in consumption should be added to school curricula as part of financial education.

- To put the concept of moderation into practice, the government should impose stringent rules and regulations prohibiting extravagant activities (wasting food at restaurants and social events, owning many cars, etc.).

- Religious authorities should promote awareness of moderation and a rejection of miserliness and wastefulness.

- Moderation should be fostered in all sectors of society via government and company policies implemented by the relevant authorities.

\section{Notes}

* Hossain Biplob is a postgraduate student at the School of Banking and Finance, Faculty of Business and Management, Universiti Sultan Zainal Abidin, Kuala Terengganu, Terengganu, Malaysia. Email: hossainbiplob362@gmail.com

** Md. Faruk Abdullah is a Senior Lecturer at the School of Banking and Finance, Faculty of Business and Management, Universiti Sultan Zainal Abidin, Kuala Terengganu, Terengganu, Malaysia. Email: farukabdullah77@gmail.com

1. Fatimah Abdullah and Amirah Adnan, 'Hamka's Concept of Moderation: An Analysis,' Journal of Islam in Asia 2 (2011): 358-75.

2. Hamka, Falsafah Hidup (Jakarta: Umminda, 1984), 144.

3. Ibrahim Ramjuan, 'Islam and Luxury Consumption,' ResearchGate. Available at: https://www.researchgate.net/ publication/324828495_Islam_ and_Luxury_Consumption, 1-16.

4. Roslily Ramlee, Sharifah Raihan Sayed Mohd Zain and Wan Rohaida Wan 
Hussain, 'Are Muslims Practicing Moderation in their Financial Decisions,' Asian Academy of Management Journal 24, no. 1 (2019): 157-70.

5. Kim Shyan Fam, David S. Waller and B. Zafer Erdogan, 'The Influence of Religion Towards the Advertising of Controversial Products,' European Journal of Marketing 38, no. 5/6 (2004): 537-55.

6. Roslily, Sharifah Raihan and Wan Rohaida, 'Are Muslims Practicing Moderation,' 157-70.

7. Ghazali Basri, Dinamika Tasawwur Islam Dalam Pembentukan Keperibadian Umat, trans. Mohd. Mokhtar Syafii (Bandar Seri Begawan: Kolej Universiti Perguruan Ugama Seri Begawan, 2008).

8. Abdullah Mat Zin, 'Wasatiyyah Dalam Hubungan Kaum,' Dewan Tamadun Islam 11 (2013): 4-8.

9. Al-Qur'an, 2:143.

10. Abu 'Abd Allah Muhammad bin Ahmad al-Ansariy, Al-Jami' li Ahkam alQur'an, vol. 1 (Beirut: Dar al-Kutub al-'Ilmiyyah, 1993).

11. Abi Ja'far Muhammad bin Jarir al-Tabariy, Tafsir al-Tabariy al-Musamma Jami ' al-Bayan fi Ta'wil al-Qur'an, vol. 2 (Beirut: Dar al-Kutub al-'Ilmiyyah, 1993).

12. Fakhr al-Din al-Raziy, Al-Tafsir al-Kabir aw Mafatih al-Ghayb, vol. 2 (Beirut: Dar al-Kutub al-'Ilmiyyah, 1990).

13. Ali Mohammad Al-Sallabi, Al-Wasatiyyah fi al-Qur'an al-Karim (Amman: Dar al-Nafais \& Dar al-Bayariq, 1999).

14. Mohammad Rashid Rida, Tafsir al-Manar, vol. 2 (Cairo: Al-Hay'ah alMisriyyah al-Ammah li al-Kitab, 1990).

15. Hamka, Falsafah Hidup, 144.

16. Donald Rutherford, Economics: The Key concepts (London and New York: Routledge, 2007), 215-7.

17. M. Umer Chapra, 'Ethics and Economics: An Islamic perspective,' Islamic Economics Studies 16, no. 1-2 (2008): 1-24.

18. Masudul Alam Chowdhury, 'The Micro-economic Foundations of Islamic Economics: A Study in Social Economics,' American Journal of Islamic Social Science 3, no. 2 (2019): 231-45.

19. Nurizal Islam and Syafii Muhammad Antonio, 'The Islamic Wealth Management: An Analysis from Ibn Sina's Perspective,' Journal of Islamic Thought and Civilization 2, no. 3 (2012): 19-36.

20. Ibn Sina, 'Kitab al-Siyashah, ed. Louis Ma'luf,' in Maqalat Falsafiyyah Qadimah li Ba'di Masyahirih Falasifah al-'Arab Muslimin wa Nasara, ed. Louis Cheikho et al., (Beirut: al-Matba' al-Katsulikiyyah lil Abai alyasu'iyyin, 1911), 9-10.

21. Al-Qur'an, 2:33.

22. Sahih Al-Muslim, hadith No. 995.

23. Ibn Sina, 'Kitab al-Siyashah,' 9-10.

24. Al-Qur'an, 2:143.

25. Sahih Al-Muslim, vol. 3, 97.

26. Nurizal and Syafii, 'The Islamic Wealth Management,' 19-36.

27. Hafas Furqani, 'Consumption and Morality: Principles of Behavioral Framework in Islamic Economics,' JKAU: Islamic Econ. 30 (2017): 89-102. 
28. Al Qur'an, 5:88

29. Lu'luil Hamidah, 'The Relevance of Jean Baudrillard's Exchange Philosophy of Value with Consumption Ethics in Islam.' Unpublished Undergraduate (S1) Thesis, UIN Walisongo (2014), 13-28.

30. Sahih Al-Muslim, hadith no. 1599.

31. Sheikh Khalifa Izzat, 'The Lawful and Prohibited in Islam,' London Central Mosque Trust \& The Islamic Cultural Centre. Available at: https://www. iccuk.org/media/khutbas/The $\% 20$ Lawful $\% 20$ and $\% 20$ the $\% 20$ Prohibited $\% 20$ (13-02-09).pdf., 1-2.

32. Hamidah, 'Consumption Ethics in Islam,'13-28.

33. Al-Qur'an, 14:114

34. Muhammad Sharif Chaudhry, Fundamentals of Economic Systems (Lahore: Township, 2003).

35. Furqani, 'Consumption and Morality,' 89-102.

36. Al-Qur'an, 2:215.

37. Al-Qur'an, 2:219.

38. Ahmed ibn Mustafa al-Maraghi, Tafsir al-Maraghi, vol. 2 (Cairo: Shirkah Maktabah Wa Matba'ah Mustafa al-Bab al-Halabi, 1946), 146.

39. Furqani, 'Consumption and Morality,' 89-102.

40. Al-Qur'an, 2:3.

41. Atique Tahir, Atiq uz Zafar Khan and Ataullah Khan Mahmood, 'Right to Basic Necessities of Life in Islam: Meaning and Concept,' The Dialogue 11, no. 2 (2011): 202-12.

42. Sunan al-Tirmidhi, hadith No. 2320.

43. Sharif Chaudhry, Fundamentals of Economic Systems.

44. Farzana Quoquab, Nor Liza Abdullah and Maisarah Ahmed, 'Epicureanism and Global Consumerism in Shaping Muslim Buyers' Consumption Pattern: An Islamic Perspective,' International Journal of Innovation and Business Strategy 3 (2015): 1-12.

45. Ibrahim Ibn Musa al-Shatibi, Al-Muwafaqat Fi Usul al-Shari 'ah, ed. Abu 'Ubaydah Mashhur Ibn Hasan Ali Salman, vol. 2 (Khobar: Dar Ibn 'Affan, 1997), 22.

46. Mohd Shukri Hanapi, 'The Wasatiyyah concept in Islamic Epistemology: A Case Study of its Implementation in Malaysia,' International Journal of Humanities and Social Science 4, no. 9(1) (2014): 51-62.

47. Basharat Hossain, 'Application of Islamic Consumer Theory: An Empirical Analysis in the context of Bangladesh,' Global Review of Islamic Economics and Business 2, no. 1 (2014): 69-83.

48. Al-Qur'an, 4:37.

49. Muhammad ibn Ali ibn Muhammad ibn 'Abdullah al-Shawkani, Fath alQadir (Beyrut: Dar Ibn Kathir, 1414H).

50. Abul al-Hasan Ali al-Mawardi, Tafsir al-Mawardi, vol. 3 (Beirut: Dar alKutub al-'Ilmiyyah, n.d.), 118.

51. Sunan Ibn Majah, hadith No. 425.

52. Hussein A. Amery, 'Islamic Water Management,' Water International 26, no. 4 (2001): 481-9.

53. Basharat Hossain, 'Application of Islamic Consumer Theory,' 69-83. 
54. Al-Qur'an, 17:26.

55. Al-Shawkani, Fath al-Qadir, vol. 3, 263.

56. Hossain Biplob and Md. Faruk Abdullah, 'The Importance of Islamic Financial Literacy,' Islam and Civilisational Renewal 10, no. 1 (2019): 10617.

57. Al-Qur'an, 25:67

58. Musnad Ahmad, hadith no. 1135.

59. Soo Lim, 'Eating a Balanced Diet: A Healthy Life through a Balanced Diet in the Age of Longevity,' Journal of Obesity and Metabolic Syndrome 27, no. 1 (2018): 39-45.

60. Orose Leelakulthanit, 'Factors Affecting life in Moderation,'Asian Social Science 13, no. 1 (2017): 106-13.

61. Rajasekharan Pillai, Rozita Carlo and Rachel D'souza, 'Financial Prudence Among Youths,' Munich Personal Repec Archive (2010): 1-22.

62. Biplob and Abdullah, 'The Importance of Islamic Financial Literacy,' 10617.

63. Furqani, 'Consumption and Morality,' 89-102.

64. Leelakulthanit, 'Factors Affecting life in Moderation,' 106-13.

65. Pasrun Adam, 'An Analysis of The Effect of Consumption Spending and Investment on Indonesia's Economic Growth,' Iran Economic Review 22, no. 3 (2018): 1-15.

\section{Bibliography}

Abdullah, Fatimah, and Amirah Adnan. 'Hamka's Concept of Moderation: An Analysis.' Journal of Islam in Asia, no. 2 (2011): 358-75.

Adam, Pasrun. 'An Analysis of the Effect of Consumption Spending and Investment on Indonesia’s Economic Growth.' Iran Economic Review 22, no. 3 (2018): 1-15.

Al-Ansariy, Abu 'Abd Allah Muhammad bin Ahmad. Al-Jami' li Ahkam al-Qur'an. Vol. 1. Beirut: Dar al-Kutub al-'Ilmiyyah, 1993.

Al-Maraghi, Ahmed ibn Mustafa. Tafsir al-Maraghi. Vol. 2. Cairo: Shirkah Maktabah wa Matba'ah Mustafa al-Bab al-Halabi, 1946.

Al-Mawardi, Abul al-Hasan Ali. Tafsir al-Mawardi. Vol. 3. Beirut: Dar al-Kutub al'Ilmiyyah, n.d.

Al-Raziy, Fakhr al-Din. Al-Tafsir al-Kabir aw Mafatih al-Ghayb. Vol. 2. Beirut: Dar al-Kutub al-'Ilmiyyah, 1990.

Al-Sallabi, Ali Mohammad. Al-Wasatiyyah fi al-Qur'an al-Karim. Amman: Dar alNafais wa Dar al-Bayariq, 1999.

Al-Shatibi, Ibrahim Ibn Musa. Al-Muwafaqat fi Usul al-Shari'ah. Edited by Abu 'Ubaydah Mashhur ibn Hasan Ali Salman. Vol. 2. Khobar: Dar Ibn 'Affan, 1997. 
Al-Shawkani, Muhammad ibn Ali ibn Muhammad ibn 'Abdullah. Fath al-Qadir. Beyrut: Dar Ibn Kathir, 1414H.

Al-Tabariy, Abi Ja'far Muhammad bin Jarir. Tafsir al-Tabariy al-Musamma Jami ‘ alBayan fi Ta'wil al-Qur'an. Vol. 2. Beirut: Dar al-Kutub al-'Ilmiyyah,1993.

Amery, Hussein A. 'Islamic Water Management.' Water International 26, no. 4 (2001): 481-9.

Basri, Ghazali. Dinamika Tasawwur Islam Dalam Pembentukan Keperibadian Umat. Translated by Mohd. Mokhtar Syafii. Bandar Seri Begawan: Kolej Universiti Perguruan Ugama Seri Begawan, 2008.

Biplob, Hossain, and Md. Faruk Abdullah. 'The Importance of Islamic Financial Literacy.' Islam and Civilisational Renewal 10, no. 1 (2019): 106-17.

Chapra, M. Umer. 'Ethics and Economics: An Islamic Perspective.' Islamic Economics Studies 16, no. 1 and 2 (2008): 1-24.

Chaudhry, Muhammad Sharif. Fundamentals of Economic Systems. Lahore: Township, 2003.

Chowdhury, Masudul Alam. 'The Micro-Economic Foundations of Islamic Economics: A Study in Social Economics.' American Journal of Islamic Social Science 3, no. 2 (2019): 231-45.

Fam, Kim Shyan, David S. Waller and B. Zafer Erdogan. 'The Influence of Religion Towards the Advertising of Controversial Products.' European Journal of Marketing 38, no. 5/6 (2004): 537-55.

Furqani, Hafas. 'Consumption and Morality: Principles of Behavioral Framework in Islamic Economics.' JKAU: Islamic Econ. 30 (2017): 89-102.

Hamidah, Lu'luil. 'The Relevance of Jean Baudrillard's Exchange Philosophy of Value with Consumption Ethics in Islam.' Unpublished Undergraduate (S1) Thesis, UIN Walisongo, 2014.

Hamka. Falsafah Hidup. Jakarta: Umminda, 1984.

Hanapi, Mohd Shukri. 'The Wasatiyyah concept in Islamic Epistemology: A Case Study of its Implementation in Malaysia.' International Journal of Humanities and Social Science 4, no. 9(1) (2014): 51-62.

Hossain, Basharat. 'Application of Islamic Consumer Theory: An Empirical Analysis in the Context of Bangladesh.' Global Review of Islamic Economics and Business 2, no. 1 (2014): 69-83.

Ibn Sina. 'Kitab al-Siyashah, ed. Louis Ma'luf.' In Maqalat Falsafiyyah Qadimah li Ba'di Masyahirih Falasifah al-'Arab Muslimin wa Nasara. Edited by Louis Cheikho et al., 9-10. Beirut: al-Matba' al-Katsulikiyyah lil Abai al-yasu'iyyin, 1911.

Islam, Nurizal, and Syafii Muhammad Antonio. 'The Islamic Wealth Management: An Analysis from Ibn Sina's Perspective.' Journal of Islamic Thought and 
Civilization 2, no. 3 (2012): 19-36.

Izzat, Sheikh Khalifa. 'The Lawful and Prohibited in Islam,' London Central Mosque Trust \& The Islamic Cultural Centre. Available at: https://www.iccuk.org/media/ khutbas/The\%20Lawful\%20and\%20the\%20Prohibited\%20 (13-02-09).pdf.

Leelakulthanit, Orose. 'Factors Affecting life in Moderation.' Asian Social Science 13, no. 1 (2017): 106-13.

Lim, Soo. 'Eating a Balanced Diet: A Healthy Life through a Balanced Diet in the Age of Longevity.' Journal of Obesity and Metabolic Syndrome 27, no. 1 (2018): $39-45$.

Mat Zin, Abdullah. 'Wasatiyyah Dalam Hubungan Kaum.' Dewan Tamadun Islam 11 (2013): 4-8.

Pillai, Rajasekharan, Rozita Carlo and Rachel D'souza. 'Financial Prudence Among Youths.' Munich Personal Repec Archive (2010): 1-22.

Quoquab, Farzana, Nor Liza Abdullah and Maisarah Ahmed. 'Epicureanism and Global Consumerism in Shaping Muslim Buyers' Consumption Pattern: An Islamic Perspective.' International Journal of Innovation and Business Strategy 3 (2015): 1-12.

Ramjuan, Ibrahim. 'Islam and Luxury Consumption,' ResearchGate. Available at: https://www.researchgate.net/publication/324828495_Islam_and_Luxury_ Consumption, 1-16.

Ramlee, Roslily, Sharifah Raihan Sayed Mohd Zain and Wan Rohaida Wan Hussain. 'Are Muslims Practicing Moderation in their Financial Decisions.' Asian Academy of Management Journal 24, no. 1 (2019): 157-70.

Rida, Mohammad Rashid. Tafsir al-Manar. Vol. 2. Cairo: Al-Hay'ah al-Misriyyah al-Ammah li al-Kitab, 1990.

Rutherford, Donald. Economics: The Key Concepts. London and New York: Routledge, 2007.

Tahir, Atique, Atiq uz Zafar Khan and Ataullah Khan Mahmood. 'Right to Basic Necessities of Life in Islam: Meaning and Concept.' The Dialogue 11, no. 2 (2011): 202-12. 